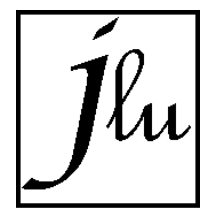

https://jurnal.univpgri-

palembang.ac.id/index.php/luminous
Jurnal Luminous 02 (2) (2021) 38 - 42

Riset Ilmiah Pendidikan Fisika

Vol. 2 No. 2 (2021) hal 38
E-ISSN 2715-6990

P-ISSN 2715-9582

082021

\title{
ANALISIS PENGGUNAAN E-MODUL DALAM PEMBELAJARAN FISIKA: STUDI LITERATUR
}

\author{
Saprudin $^{1 *}$, Ade Hi Haerullah ${ }^{2}$, Fatma Hamid ${ }^{3}$ \\ ${ }^{1}$ Program Studi Pendidikan Fisika, Fakultas Keguruan dan Ilmu Pendidikan, Universitas Khairun \\ Jalan Bandara Baabullah Kota Ternate, Indonesia \\ saprudin@unkhair.ac.id \\ ${ }^{2}$ Program Studi Pendidikan Biologi, Fakultas Keguruan dan IImu Pendidikan, Universitas Khairun \\ Jalan Bandara Baabullah Kota Ternate, Indonesia \\ biohaerullah@gmail.com \\ ${ }^{3}$ Program Studi Pendidikan Fisika, Fakultas Keguruan dan Ilmu Pendidikan, Universitas Khairun \\ Jalan Bandara Baabullah Kota Ternate, Indonesia \\ fatma_hamid37@yahoo.co.id
}

Received: 3005 2021. Accepted: 2007 2021. Published: 072021

\begin{abstract}
Abstrak
Artikel ini merupakan bagian dari penelitian terkait pengembangan e-modul Ilmu Pengetahuan Alam (IPA) berorientasi keterampilan berpikir kreatif siswa Sekolah Menengah Pertama (SMP). Artikel ini mendeskripsikan salah satu hasil analisis kebutuhan yakni studi literatur berupa kajian penelitian terdahulu terkait penggunaan e-modul dalam pembelajaran fisika. Metode yang digunakan dalam penelitian ini adalah studi literatur yakni kajian artikel-artikel hasil penelitian terkait penggunaan e-modul dalam pembelajaran fisika yang dipublikasikan pada jurnal maupun prosiding. Kajian dibatasi pada jurnal dan prosiding berbahasa indonesia. Berdasarkan hasil kajian yang dilakukan, disimpulkan bahwa e-modul telah banyak digunakan dalam pembelajaran fisika. Pengembangan emodul dalam pembelajaran fisika ditujukan untuk meningkatkan keterampilan berpikir kritis, meningkatkan keterampilan proses sains, literasi sains, motivasi serta hasil belajar siswa. E-modul dapat dirancang dengan menggunakan software 3D pageflip professional, adobe animate CC, sigil, kvisoft flipbook maker, exe-Learning, aplikasi berbasis android atau integrasi aplikasi CMS wordpress, Youtube dan QMS classmarker. Hasil kajian ini dapat dimanfaatkan sebagai acuan dalam melakukan pengembangan emodul dalam pembelajaran fisika di masa yang akan datang.
\end{abstract}

Kata Kunci: e-modul, Pembelajaran fisika, Software

(C) 2021 Pendidikan Fisika FKIP UPGRI Palembang

\section{PENDAHULUAN}

Salah satu tantangan Belajar Dari Rumah

(BDR) dalam pembelajaran IImu Pengetahuan
Alam (IPA) di Sekolah Menengah Pertama (SMP) adalah bagaimana guru dapat mengemas konten materi pembelajaran yang menarik serta dapat memudahkan siswa untuk memahami konsepkonsep IPA. Melalui pengemasan konten 
pembelajaran yang menarik diharapkan dapat memotivasi siswa untuk dapat belajar secara mandiri. Salah satu bentuk bahan ajar yang tepat untuk digunakan dalam kegiatan belajar mandiri adalah modul.

Dalam konteks pembelajaran, modul merupakan unit pengajaran yang lengkap yang dirancang untuk dipergunakan oleh seorang atau sekelompok kecil siswa tanpa kehadiran guru (Smaldino et al., 2011). Pada jenjang perguruan tinggi, modul berbeda dengan buku ajar, diktat, petunjuk praktikum dan naskah tutorial. Modul merupakan bagian dari bahan ajar untuk suatu mata kuliah yang ditulis oleh dosen mata kuliah tersebut, mengikuti kaidah tulisan ilmiah dan disebarluaskan pada peserta kuliah (Kemenristekdikti, 2019). Sejalan dengan hal itu, Wiyoko (2014) menyatakan bahwa modul merupakan suatu bahan ajar yang dirancang secara sistematis dengan bahasa yang mudah dipahami oleh siswa sesuai dengan tingkat pengetahuan dan usia mereka, agar mereka dapat belajar mandiri dengan atau tanpa bantuan dan bimbingan dari guru. Modul juga dipandang sebagai bahan ajar yang dapat digunakan oleh siswa untuk belajar secara mandiri dengan bantuan seminimal mungkin dari orang lain (Munadi, 2008).

Perkembangan teknologi dalam hal ini software yang semakin pesat dan relatif mudah diakses memungkinkan modul didesain dalam bentuk modul elektronik (e-modul) yang dapat mengintegrasikan teks, gambar, video, simulasi, animasi, kuis dan evaluasi secara interaktif. Melalui e-modul, proses pembelajaran dapat melibatkan tampilan audio visual, sound, movie serta navigasi sehingga siswa dapat lebih interaktif dengan program yang dirancang (Sugianto dkk, 2013).

Artikel ini mendeskripsikan kajian terkait penggunaan e-modul dalam pembelajaran fisika melalui pengkajian terhadap hasil penelitian yang dipublikasikan pada jurnal maupun prosiding berbahasa indonesia. Hasil kajian ini dapat dimafaatkan sebagai acuan dalam melakukan pengembangan e-modul dalam pembelajaran fisika di masa yang akan datang.

\section{METODE}

Metode yang digunakan dalam penelitian ini adalah studi literatur. Peneliti melakukan kajian hasil penelitian terkait penggunaan e-modul dalam pembelajaran fisika yang telah dipublikasikan pada jurnal maupun prosiding berbahasa Indonesia. Teknik pengumpulan data penelitian ini menggunakan data sekunder yakni artikel-artikel penelitian yang relevan (Ayudha \& Setyarsih, 2021).

Hasil kajian dideskripsikan berdasarkan dua fokus utama yaitu; 1) orientasi penggunaan emodul dalam pembelajaran fisika dan 2) software yang digunakan untuk merancang e-modul dalam pembelajaran fisika.

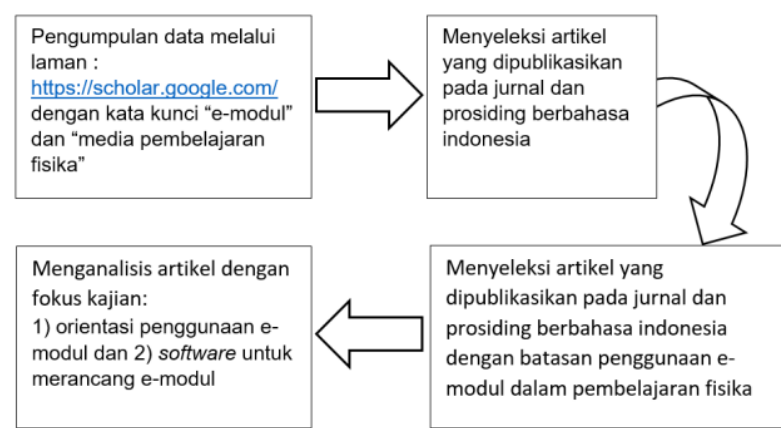

Gambar 1. Prosedur Pengumpulan dan Analisis Data

\section{HASIL DAN PEMBAHASAN}

\section{Orientasi Penggunaan e-Modul dalam Pembelajaran Fisika}

Berdasarkan hasil analisis terhadap artikel hasil penelitian yang dipublikasi pada jurnal maupun prosiding berbahasa indonesia, penggunaan e-modul dalam pembelajaran fisika dapat ditunjukkan pada Tabel 1.

Hasil analisis pada tabel 1 menunjukkan bahwa penggunaan e-modul dalam pembelajaran fisika dapat meningkatkan keterampilan berpikir 
kritis (Sujanem dkk, 2020; Puspitasari, 2019; Latifah dkk, 2020), keterampilan proses sains (Mayanty dkk, 2018; Sumiati dkk, 2018), dan meningkatkan hasil belajar siswa (Suyoso \& Nurohman, 2014; Latifah dkk, 2020; Puspitasari, 2019). Dalam pengembangannya, untuk mencapai tujuan pembelajaran maka e-modul dapat diintegrasikan dengan menerapkan model-model pembelajaran misalnya model problem based learning (Mayanty dkk, 2018; Agustia \& Fauzi, 2020), model learning cycle 5E (Gustiningrum dkk, 2019) dan model inkuiri terbimbing (Haspen \& Festiyed, 2019).

Tabel 1. Analisis Penggunaan e-modul dalam Pembelajaran Fisika

\begin{tabular}{|c|c|c|}
\hline No & Target & Penulis \\
\hline 1 & $\begin{array}{l}\text { Keterampilan } \\
\text { berpikir kritis }\end{array}$ & $\begin{array}{l}\text { Sujanem dkk, 2020; } \\
\text { Puspitasari, } 2019 ; \\
\text { Latifah dkk, } 2020 .\end{array}$ \\
\hline 2 & $\begin{array}{l}\text { Keterampilan } \\
\text { proses sains }\end{array}$ & $\begin{array}{l}\text { Mayanty dkk, 2018; } \\
\text { Sumiati dkk, } 2018 .\end{array}$ \\
\hline 3 & Hasil belajar & $\begin{array}{l}\text { Suyoso } \& \\
\text { Nurohman, } \\
\text { Latifah dkk, 2014; } \\
\text { Puspitasari, 2019. }\end{array}$ \\
\hline 4 & Literasi sains & $\begin{array}{l}\text { Nurhasnah \& Sari, } \\
\text { 2020; Muzijah dkk, } \\
\text { 2020. }\end{array}$ \\
\hline 5 & Motivasi & Puspitasari, 2019. \\
\hline
\end{tabular}

Software yang Digunakan untuk Merancang eModul dalam Pembelajaran Fisika

Berdasarkan hasil analisis terhadap artikel hasil penelitian yang dipublikasi pada jurnal maupun prosiding berbahasa indonesia terkait penggunaan e-modul dalam pembelajaran fisika, ditemukan berbagai macam software yang digunakan untuk merancang e-modul. Beberapa software yang digunakan diantaranya software 3D pageflip professional (Andani, 2020; Sari dkk, 2017; Nurmayanti dkk, 2015), adobe animate CC (Mayanty dkk, 2018), sigil (Liana dkk, 2019; Sujanem dkk, 2020), kvisoft flipbook maker (Latifah dkk, 2020; Nurhasnah \& Sari, 2020; Mukramah dkk, 2020), exe-Learning (Muzijah dkk, 2020), aplikasi berbasis android (Aditya dkk,
2020), integrasi CMS wordpress, situs berbagi video Youtube dan QMS classmarker (Suyoso \& Nurohman, 2014).

\section{SIMPULAN}

E-modul telah banyak digunakan dalam pembelajaran fisika. E-modul dapat dirancang dengan menggunakan software 3D pageflip professional, adobe animate $\mathrm{CC}$, sigil, kvisoft flipbook maker, exe-Learning, aplikasi berbasis android atau integrasi aplikasi CMS wordpress, situs berbagi video Youtube dan QMS classmarker. Pengembangan e-modul dalam pembelajaran fisika ditujukan untuk meningkatkan keterampilan berpikir kritis, meningkatkan keterampilan proses sains, literasi sains, motivasi serta peningkatan hasil belajar siswa.

\section{UCAPAN TERIMA KASIH}

Peneliti mengucapkan terima kasih pada Dekan Fakultas Keguruan dan IImu Pendidikan (FKIP) dan kepala Lembaga Penelitian dan Pengabdian Masyarakat (LPPM) yang telah mendanai penelitian ini melalui Hibah Penelitian Kompetitif Unggulan Perguruan Tinggi tingkat Fakultas Keguruan dan IImu Pendidikan, Universitas Khairun tahun 2021.

\section{DAFTAR PUSTAKA}

Aditya, S., Haryoto, D., \& Pramono, N. A. (2020). Pengembangan Modul Elektronik Fisika Berbasis Android untuk Siswa SMA/MA Kelas $X$ Materi Momentum dan Impuls. Jurnal Riset Pendidikan Fisika, 4(2), 70-73

Agustia, F. S., \& Fauzi, A. (2020). Efektivitas EModul Fisika SMA Terintegrasi Materi Kebakaran Berbasis Model Problem Based Learning. Jurnal Penelitian Pembelajaran Fisika, 6(1), 1-8 
Andani, M. (2020). E-Modul Fisika Dasar I Berbasis 3D Pageflip Professional. Schrodinger: Journal of Physics Education, 1(2), 44-47.

Ayudha, C. F. H., \& Setyarsih, W. (2021). Studi Literatur: Analisis Praktik Pembelajaran Fisika di SMA untuk Melatih Keterampilan Pemecahan Masalah. Jurnal Pendidikan Fisika Undiksha, 11(1).

Gustiningrum, S. J., Budi, E., \& Siswoyo, S. (2019). Pengembangan E-Modul Fisika Phyheart (Physics Heat and Temperature) Berbasis Android dengan Pendekatan Learning Cycle 5E pada Materi Suhu dan Kalor untuk Siswa Sekolah Menengah Atas. In Prosiding Seminar Nasional Fisika (E-Journal) (Vol. 8, pp. SNF2019-PE).

Haspen, C. D. T., \& Festiyed, F. (2019). MetaAnalisis Pengembangan E-Modul Berbasis Inkuiri Terbimbing pada Pembelajaran Fisika. Jurnal Penelitian Pembelajaran Fisika, 5(2), 180-187

Kemenristekdikti. (2019). Pedoman Operasional Penilaian Angka Kredit Kenaikan Jabatan Akademik/Pangkat Dosen. Direktorat Jenderal Sumber Daya Iptek dan Dikti.

Latifah, N., Ashari, A., \& Kurniawan, E. S. (2020). Pengembangan e-Modul Fisika untuk Meningkatkan Kemampuan Berpikir Kritis Peserta Didik. Jurnal Inovasi Pendidikan Sains, 1(1), 1-7.

Liana, Y. R., Ellianawati, E., \& Hardyanto, W. (2019). Pengembangan E-Modul Interaktif Berbasis Android Menggunakan Sigil Software pada Materi Listrik Dinamis. In Prosiding Seminar Nasional Pascasarjana (PROSNAMPAS) (Vol. 2, No. 1, pp. 926-932).

Mayanty, S., Astra, I. M., \& Rustana, C. E. (2018, May). Pengembangan E-modul Fisika Berbasis Problem Based Learning (PBL) Untuk Meningkatkan Keterampilan Proses Sains Siswa SMA. In Quantum: Seminar Nasional Fisika, dan Pendidikan Fisika (pp. 1-13).

Mukramah, W. A. N., Jannah, M \& Wahid, M. A. (2020). E-Modul Termodinamika Berbasis Flipbook Maker. Jurnal Phi, 1(3), 1-7
Munadi, Y. (2008). Media Pembelajaran; Sebuah Pendekatan Baru. Jakarta : Gaung Persada Press

Muzijah, R., Wati, M., \& Mahtari, S. (2020). Pengembangan E-modul Menggunakan Aplikasi Exe-Learning untuk Melatih Literasi Sains. Jurnal IImiah Pendidikan Fisika, 4(2), 89-98.

Nurhasnah, N., \& Sari, L. A. (2020). E-Modul Fisika Berbasis Contextual Teaching and Learning Menggunakan Aplikasi Kvisoft Flipbook Maker Untuk Meningkatkan Literasi Sains Peserta Didik SMA/MA Kelas XI. Natural Science: Jurnal Penelitian Bidang IPA dan Pendidikan IPA, 6(1), 29-40.

Nurmayanti, F., Bakri, F., \& Budi, E. (2015). Pengembangan Modul Elektronik Fisika dengan Strategi PDEODE pada Pokok Bahasan Teori Kinetik Gas untuk Siswa Kelas XI SMA. Prosiding Simposium Nasional Inovasi dan Pembelajaran Sains, 2015, 337.

Puspitasari, A. D. (2019). Penerapan Media Pembelajaran Fisika menggunakan Modul Cetak dan Modul Elektronik pada Siswa SMA. Jurnal Pendidikan Fisika, 7(1), 1725.

Sari, W., \& Pathoni, H. (2017). Pengembangan Modul Elektronik Berbasis 3D Pageflip Professional pada Materi Konsep Dasar Fisika Inti dan Struktur Inti Mata Kuliah Fisika Atom dan Inti. Edufisika: Jurnal Pendidikan Fisika, 2(01), 38-50.

Smaldino, S. E., Lowther, D. L., \& Russell, J. D. (2011). Instructional technology and media for learning (9th ed.) Terjemahan Arif Rahman. Jakarta: Kencana Prenada Media Group

Sugianto, D., Abdullah, A. G., Elvyanti, S., \& Muladi, Y. (2013). Modul Virtual: Multimedia Flipbook Dasar Teknik Digital. Invotec, 9(2), 110-116

Sujanem, R., Suswandi, I., \& Yasa, P. (2020). Pelatihan Pembuatan E-Modul Fisika Bermuatan Keterampilan Berpikir Kritis bagi Guru Fisika SMAN 1 Mengwi. In Proceeding Senadimas Undiksha, 793801. 
Sumiati, E., Septian, D., \& Faizah, F. (2018). Pengembangan Modul Fisika Berbasis Scientific Approach untuk Meningkatkan Keterampilan Proses Sains Siswa. Jurnal Pendidikan Fisika dan Keilmuan (JPFK), 4(2), 75-88.

Suyoso, S., \& Nurohman, S. (2014). Pengembangan modul elektronik berbasis web sebagai media pembelajaran fisika. Jurnal Kependidikan: Penelitian Inovasi Pembelajaran, 44(1), 73-82

Wiyoko, T., Sarwanto, S., \& Rahardjo, D. T. (2014). Pengembangan Media Pembelajaran Fisika Modul Elektronik Animasi Interaktif untuk Kelas XI SMA Ditinjau dari Motivasi Belajar Siswa. Jurnal Pendidikan Fisika, 2(2). 